\title{
Sulfur Isotope Analysis to Examine the Provenance of Cinnabar Used in Wall Paintings in the Roman domus Avinyó (Barcelona)
}

\author{
Evanthia Tsantini $^{1, *(\mathbb{D})}$, Takeshi Minami ${ }^{2,+} \mathbb{D}$, Miguel Ángel Cau Ontiveros ${ }^{1,3,4}$, Kazuya Takahashi 5 (D) \\ and Joan Carles Melgarejo ${ }^{6}$ (D)
}

1 Equip de Recerca Arqueològica i Arqueomètrica de la Universitat de Bercelona (ERAAUB), Institut d'Arqueologia de la Universitat de Barcelona (IAUB), Universitat de Barcelona (UB), c/Montalegre 6-8, 08001 Barcelona, Spain; macau@ub.edu

2 Graduate School of Science \& Engineering Research, Kindai University, 3-4-1 Kowakae, Higashi-osaka, Osaka 577-8502, Japan; minamita@life.kindai.ac.jp

3 ICREA, Pg. Lluís Companys 23, 08010 Barcelona, Spain

4 Chercheur associé, Centre Camille Jullian, MMSH, CNRS/Université Aix-Marseille, 13094 Aix-en-Provence, France

5 RIKEN, 2-1 Hirosawa, Wako, Saitama 351-0198, Japan; kazuyat@riken.jp

6 Departament de Mineralogia, Petrologia i Geologia Aplicada, Facultat de Ciències de la Terra, Institut d'Arqueologia de la Universitat de Barcelona (IAUB), Universitat de Barcelona (UB), Martí i Franquès s/n, 08028 Barcelona, Spain; joan.carles.melgarejo.draper@ub.edu

* Correspondence: evatsantini@ub.edu; Tel.: +34-687418577

† Senior author: Takeshi Minami.

Citation: Tsantini, E.; Minami, T.; Cau Ontiveros, M.Á.; Takahashi, K.; Melgarejo, J.C. Sulfur Isotope Analysis to Examine the Provenance of Cinnabar Used in Wall Paintings in the Roman domus Avinyó (Barcelona). Minerals 2021, 11, 6.

https://dx.doi.org/10.3390/ $\min 11010006$

Received: 6 November 2020 Accepted: 19 December 2020 Published: 23 December 2020

Publisher's Note: MDPI stays neutral with regard to jurisdictional claims in published maps and institutional affiliations.

Copyright: () 2020 by the authors. Licensee MDPI, Basel, Switzerland. This article is an open access article distributed under the terms and conditions of the Creative Commons Attribution (CC BY) license (https: / / creativecommons.org/ licenses/by/4.0/).

\begin{abstract}
Wall paintings in the Roman period were used to decorate both public and private spaces; therefore, they reflect, on the one hand, ideas and convictions, and on the other, daily activities and socio-economic models. Characterizations of the pigments used in mural paintings are useful for determining the economic status of a specific settlement or the importance of a particular area or the buildings within it, since the cost of different pigments varied widely. Isotope analysis can be used to identify the provenance of pigments and to establish whether the raw materials are local, regional, or imported. This provides very important information, as it might be related to both the quality and the cost of the pigments, which, in turn, might be indicators of the socio-economic status of the area in question. The present study examines the sulfur isotope ratios of the cinnabar used in Roman wall paintings sampled from the high-status Roman Domus of Casa d'Avinyó and compares them with the ratios of the analyzed geological ores sampled at various Spanish cinnabar/mercury mines. The results exclude the possibility of the cinnabar being imported from outside the Iberian Peninsula. An isotopic analysis also suggested a few possible sources for the pigments.
\end{abstract}

Keywords: cinnabar; origin; isotope; sulfur; ICP-MS; wall paintings; Roman; Barcino; Spain

\section{Introduction}

Wall paintings reflect ideas and convictions, but also daily activities and socioeconomic models. Traditional Etruscan and Greek painters from the school of Apelles influenced Roman paintings. The Etruscans painted funerary buildings as magical evocations of spirits and gods, while the Greeks combined these evocations with the practical aim of decorating buildings and walls; finally, the Romans transformed the art of painting into a way of representing the most significant features of their lives, thus turning it into a public expression [1,2].

Characterizations of the pigments of wall paintings [3-6] are useful in evaluations of the economic status of settlements and/or the importance of particular buildings, since the cost of the pigments varied widely [7]. Isotope analysis makes it possible to determine the provenance of pigments, discerning between local, regional, and imported raw materials, 
which is especially important since it relates to both their quality and cost, and therefore, to the socio-economic status of societies, groups, or individuals.

Few measurements of $S$ stable isotope from cinnabar in Roman wall paintings in Spain have been reported [8]. However, recent methodological advances in isotope analysis have expanded the use of this technique in the identification of the origin of archaeological materials, specifically, of pigments. Several studies in which cinnabar was identified in Roman wall paintings have been published [4,9-11]. Nevertheless, very few of them have dealt with the identification of sulfur isotopes in the western Mediterranean [8-11]. All these studies have suggested Almadén as a possible source. Nonetheless, all they generally dealt with plausible sources of cinnabar in Europe, and none of them considered Spanish mines other than Almadén, although the written sources mention the presence of other cinnabar mines that were in use in antiquity in the Iberian Peninsula.

The present contribution, therefore, represents step forward in this field of research, since it aims to compare the sulfur isotope values detected in the cinnabar used in Roman mural paintings in the high-class Roman domus Avinyó in Barcino (Barcelona) with the values of those isotopes in the cinnabar ores sampled at several Spanish mines (Figure 1, Table 1). The sampled mines include the most important $\mathrm{Hg}$-bearing mines in the former Hispania and nearby areas, as well as the cinnabar of different geological formation processes. We also present values of $\mathrm{S}$ isotopes detected in other Spanish Roman wall paintings in our previous research (Table 1, indicated with PBAD) [8] and consider the already-published values detected for other European or Asian cinnabar for the sake of comparison (Table 1).

\subsection{History of Use and Preparation of Cinnabar in Antiquity}

Cinnabar is a natural mineral with chemical formula HgS, that crystallizes in the trigonal system. It was used in antiquity to obtain a bright reddish-orange color. It was applied as a pigment on ceramics, walls, and tattoos, and was also used in religious ceremonies. References by Classical Greek and Roman authors to cinnabar include that of Theophrastus of Eresus (371-286 BC), and later, references to the processing of quicksilver appear in the works of Vitruvius (1st century BC) and Pliny the Elder (1st century AD). The difficult, time-consuming, and dangerous process of producing the pigment made it particularly valued and expensive.

Cinnabar was, in fact, one of the most expensive pigments in the Roman period [4]. It cost up to 300 assem, much more than Egyptian Blue, a pound of which cost 100 assem [7]. Vitruvius Polion [2] mentions that the pigment was prepared by breaking, grinding, and homogenizing the natural mineral in iron bowls and heating it continuously until all the impurities disappeared and the toxicity was eliminated, obtaining a strong and stable red color. He also noted that the pigment remained stable (and thus, retained its pure red color) only if it was not exposed to the heat of the sun; therefore, it could only be used for interior decoration. We know now that when cinnabar is heated, it turns grey-black because its crystalline structure changes and it is transformed into meta-cinnabar $\left(\mathrm{a}^{\prime}-\mathrm{HgS}\right)$. Moreover, cinnabar may be protoxidized by sunlight to a black mixture of cinnabar and native mercury [12].

The Neolithic site of Çatalhöyük in Turkey (7000-8000 BC) is one of the earliest known sites where cinnabar was used as pigment [13]. In the Iberian Peninsula, its use began later, in approximately 5300 BC. It was found in Casa Montero (Madrid, Neolithic mine) in burial sites, such as La Pijotilla (Badajoz; Chalcolithic site) and Montelirio (Sevilla, Bronze Age/Megalithic) [14], and some Neolithic funerary sites at various localities in Extremadura [15].

\subsection{Cinnabar Mines in Spain: A History of Use}

Cinnabar normally occurs in the veins and impregnations of recent volcanic rocks and some hypothermally altered deposits. Dozens of cinnabar mines are known in Spain, including: Almadén (Castilla la Mancha); Tarna and many others (Asturias); Sta. Cecilia 
(Navarra); Riaño (León); Baza and Cástaras (Granada); Oriola (Alacant); Alfondeguilla, Xóvar, and Betxí (Castelló); and Minas de Mariquita-Usagre-Badajoz and TorrejoncilloCáceres (Extremadura) (Figure 1).

The mining of mercury and cinnabar in some of those mines dates back more than 2000 years. Almadén's mining district (a vast mining area with world-class deposits) is one of the oldest known cinnabar mines in the world [16-20]. Almadén was already a famous mercury and cinnabar mine in the Roman period. As mentioned, Plini Secundi [7] remarked that during Roman times, most of the supplies came from Sisinopo (the name of Almadén before the Arab invasion). Later, when the Arabs invaded Iberia, the mines came under the control of the Caliphs, who modernized the mining of mercury. The Arab influence is also reflected in the linguistic legacy, since Al-mahden (mine) and azogue (mercury) are words of Arabic origin. Nevertheless, other, smaller mines with high-quality cinnabar ores are distributed in other areas of Spain (Figure 1).

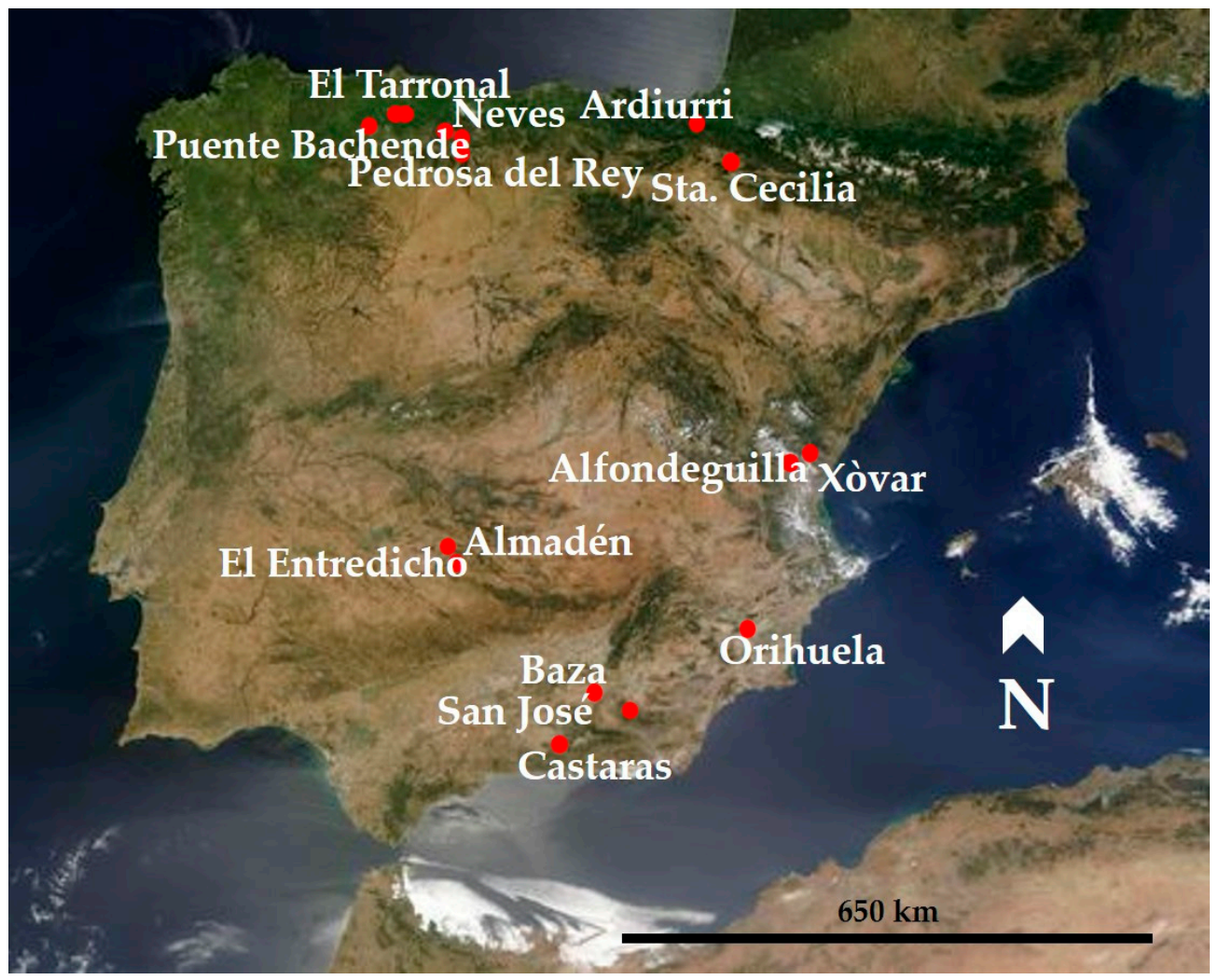

Figure 1. Map with the location of the sampled mines.

The district of Almaden, in Ciudad Real (Spain), was the most important area of mercury extraction in the world for centuries. Its deposits are strata-bound and vertically oriented. The layers of cinnabar increase in width the deeper you dig [20]. Therefore, since the 16th century, it was necessary to dig deeper in the mine to find high quality cinnabar ore [21]. The cinnabar of Almadén formed by hydrothermal alterations of sedimentary rocks coupled with biogenic processes (involving the action of bacteria); therefore, isotope variability in Almadén is quite high inside a given mineralized body. Almadén is one of the biggest known mercury deposits in the world [22,23]. It was formed by three lenticular, strata-bound cinnabar impregnations in the two quartzite members of the Criadero quartzite formation from the Lower Silurian period and, to a lesser extent, in Devonian quartzite, as in the El Burcio deposit [24], next to a phreatomagmatic explosion breccia locally called "Frailesca" [12] produced in connection with an alkaline magmatism event [24]. In addition to the world-class Almadén mine, other important deposits of the district of similar structure and importance include the El Entredicho and Vieja Concepción [25]. 
Other deposits, including Las Cuevas, Nuevo Entredicho, Nueva Concepción, Corchuelo, and Guadalperal, are found in fractures and breccias in the frailesca diatreme [26-28].

The deposits of Almadén have the greatest concentration of mercury on Earth, and since ancient times, it has been estimated to contain approximately 250,000 MT of the metal, which represents about one-third of the total used by humankind throughout history. The variability of the $\delta^{34} S$ isotopic signature of cinnabar is rather small within each of the three bodies, while its average values differ considerably among the different veins, indicating three different mineralization episodes and processes [17]. García Gomez et al. [22] reported a mercury content around $8 \%$ in most areas, i.e., quite a bit higher than any other mercury mine that they mention. The values of $\mathrm{Hg}$ content that they provide for the mines of Abbadia San Salvatore, in Monte Amiata (Italy), are between $0.6 \%$ and $2 \%$. In Idria (Slovenia), this value ranges from $1.5 \%$ to $3.2 \%$. However, the literature generally reports values that oscillate between -1.6 and $9[10,11,21]$. Spangenberg et al. [11] report values for $\mathrm{S}$ isotopes in Almadén of between -0.5 and 8.9.

There is little historical information on the use of other mines beside Almadén for the procurement of cinnabar during antiquity. The mines located in western Asturias [29] were already known and exploited in the Roman period (1st to 2nd centuries AD). Various Latin historians (Lucan, Martial, Claudian, Lucius Annaeus Florus, Silius Italicus, and, above all, Plini the Elder) described the evolution of the mining works in the northwest of the Iberian Peninsula, the decline of which must have coincided with the partial exhaustion of the gold mines in the western area of Asturias. In the Roman period (1st to 2nd centuries AD), gold was extracted in large open pits in western Asturias; there is also evidence of the extraction of mercury, copper, iron, and lead ores. The decline of these mines coincided with the partial depletion of gold mines in the western zone towards the end of the 2nd century or early 3rd century [30]. In spite of the fact that some powdery cinnabar is produced by the weathering of $\mathrm{Hg}$-bearing sphalerite in several mines [30,31], primary crystalline cinnabar was mostly produced by hydrothermal replacement of Paleozoic limestones [31,32].

Archaeological evidence of exploitations of copper and cinnabar is also provided in the Castilla and León region [33], especially in the Riaño area. The Asunción mine in Pedrosa del Rey was known to the Romans and even to those before them. This mine produced cinnabar and realgar in antiquity, among other minerals. The mine was in continuous activity until the beginning of the 1970s. Scarce cinnabar, along with fluorite, calcite, realgar, and stibnite, crystallized, replacing black limestones [33].

Proof of the existence of mining in antiquity is not available for the rest of the Spanish cinnabar mines, and the geological data are also relatively scarce. The mines of the XòvarBetxí mining district are the best known among them. These mines were exploited at least by the Arabians in the Early Middle Ages. Powdery cinnabar formed in dolomite or barite veins, cutting Triassic sandstones and dolostones; in these deposits, powdery cinnabar was produced by the supergene replacement of $\mathrm{Hg}$-rich tetraedrite [34]. Other mines include the Usagres area in Extremadura [21].

\section{Sampling and Analytical Method}

\subsection{The Site, the Sampled Contexts, and the Sampling of Wall Paintings}

The Roman occupation of the Iberian Peninsula started after the Second Punic War. The north-east of the Iberian Peninsula was the first region to fall under Roman control and served as a base for further expansion. The Roman colony of Barcino was founded in the time of Augustus in the first century BC. Even though it was smaller than other cities, its strategic position on a branch of the Via Augusta allowed its commercial and economic development. By the 2nd century, the city had a population of 3500-5000, and its main economic activity was agriculture (wine, cereals, etc.). After AD 250, when the first raids by the Germanic tribes started, the fortifications of the city were substantially improved, and a new double-wall fortification increased the importance of Barcino.

The domus Avinyó is a Roman house built in the 1st century and refurbished in the 4th century. It was discovered during the 2004 excavation of a street called Avinyó, from which 
the house takes its name. The house is in the south-west of the Roman city (Figure 2A), in the old suburbia surrounded by the Roman wall. The domus (Figure 2B) was located facing three streets of the urban layout. It is composed of living areas, as well as production areas used for metallurgy, pottery-making activities, salting, and other activities.

The domus belonged to a wealthy family of Roman Barcino. The walls and the roof were all decorated with wall paintings (Figure $2 \mathrm{C}-\mathrm{F}$ ). This large set of Roman wall paintings of great technical and decorative quality is, to date, unique in the city of Barcelona. All of them are now preserved and exhibited in the Museum of History of Barcelona [35] (the conservation effort was led by Mrs. Lídia Font). They date from between the 1st and 2nd century AD and were executed with excellent technical knowledge and means. The best conserved are those that were discovered in the Triclinium and the Cubiculum. The decorations are both figurative and geometrical (Terpsichore and the muse and imaginary architectural elements) (Figure 2C,F). The decoration of the roof of the Cubiculum is well preserved, and it is full of floral and geometrical elements, with green, red, and black as the dominant colors (Figure 2D,E). The scene of the abduction of Ganymede ("the most beautiful of mortals," according to Homer's Iliad), who was transformed into a hawk by Zeus, is also represented on the roof. The high status of the domus is supported by the fact that the red pigments used are exclusively cinnabar.

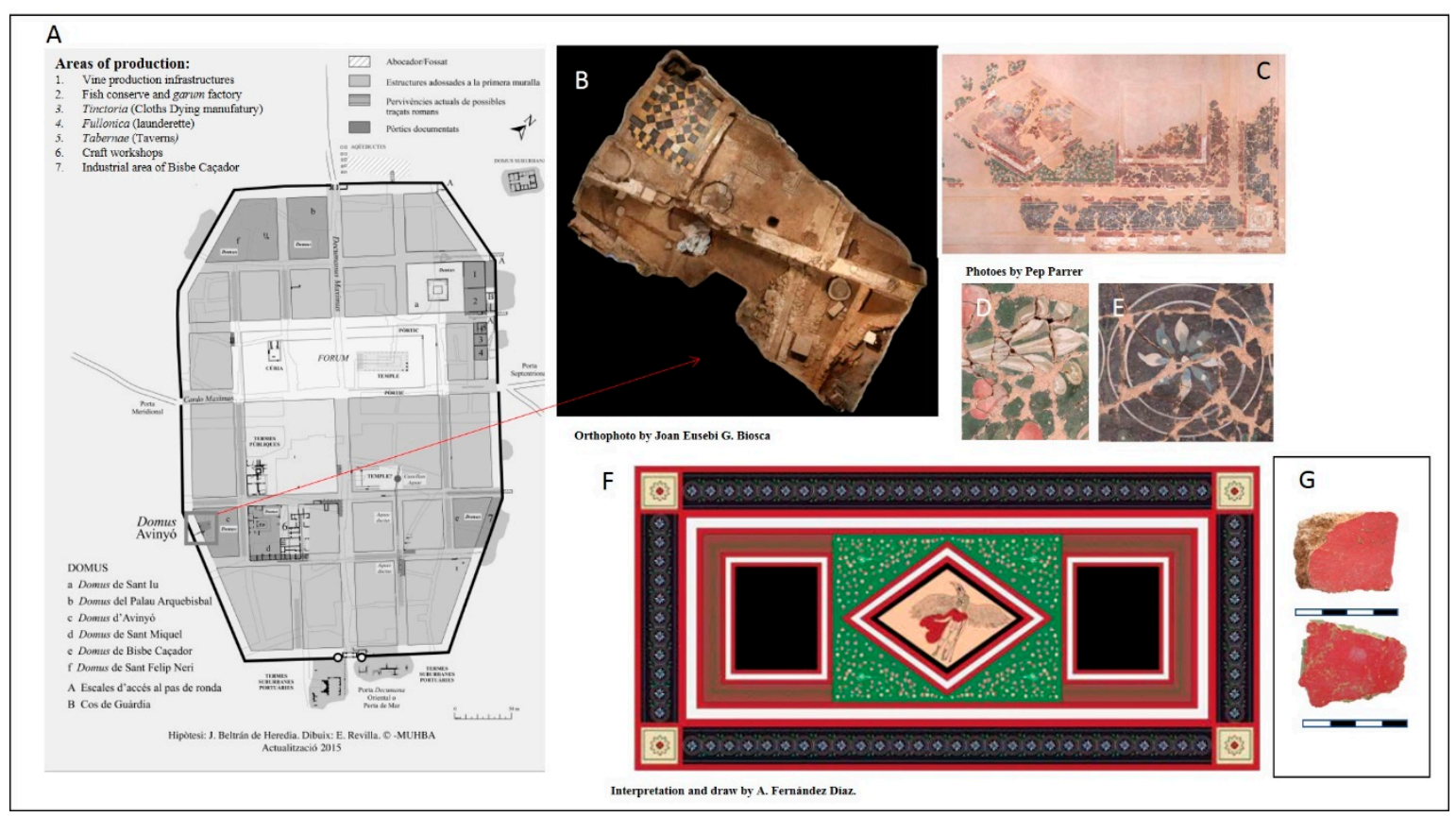

Figure 2. (A) The plan of Barcino [35]. (B) Orthophoto of the plan of the domus Avinyó [35]. (C-E): Wall paintings from the Triclinium and the Cubiculum [35]. (F): Interpretation of the central scene: Terpsichore and the muse [35]. (G): Two random fragments that the pigments BAR1a and BAR5e come from, presented as an example.

We present a list of samples from the domus and the mines in Table 1. For the sampling of the pigments, we used an $\mathrm{S}$ free tape, taking the smallest possible sample from the external surface of the mural paintings. We sampled the maximum number of available cinnabar mines in Spain (Table 1; Figure 1) and, in cases where there was a high variability of the $\mathrm{S}$ isotopes in previous studies (Almadén, Asturias, León) [8], multisampling was also carried out. In the comparison, we included our previous results on Roman pigments (PBAD in Table 1) and the values for both pigments and mines already published in the literature (Table 1). 
Table 1. List of the samples and the raw isotopic values of $S$ isotopes and the mean and standard deviation for each one of the mines and the pigments.

\begin{tabular}{|c|c|c|c|c|}
\hline Type of Sample & Samples & S Isotopes & Mean Isotoic Value & SD \\
\hline Cinnabar mineral & Almaden (Ciudad Real/Castilla a la Mancha) & 5.04 & & \\
\hline Cinnabar mineral & Almaden (Ciudad Real/Castilla a la Mancha) & 8.17 & & \\
\hline Cinnabar mineral & Almaden (Ciudad Real/Castilla a la Mancha) & 6.741 & & \\
\hline Cinnabar mineral & Almaden (Ciudad Real/Castilla a la Mancha) & 6.8 & & \\
\hline Cinnabar mineral & Almaden (Ciudad Real/Castilla a la Mancha) & 7.34 & & \\
\hline Cinnabar mineral & Almaden (Ciudad Real/Castilla a la Mancha) & 4.23 & & \\
\hline Cinnabar mineral & Almaden (Ciudad Real/Castilla a la Mancha) & 6.37 & & \\
\hline Cinnabar mineral & Almaden (Ciudad Real/Castilla a la Mancha) & 9.61 & & \\
\hline Cinnabar mineral & Almaden (Ciudad Real/Castilla a la Mancha) & 11.15 & & \\
\hline Cinnabar mineral & Almaden (Ciudad Real/Castilla a la Mancha) & 10.77 & 8.51 & 3.23 \\
\hline Cinnabar mineral & Almaden (Ciudad Real/Castilla a la Mancha) & 9.62 & & \\
\hline Cinnabar mineral & Almaden (Ciudad Real/Castilla a la Mancha) & 12.5 & & \\
\hline Cinnabar mineral & Almaden (Ciudad Real/Castilla a la Mancha) & 6.855 & & \\
\hline Cinnabar mineral & Almaden (Ciudad Real/Castilla a la Mancha) & 7.61 & & \\
\hline Cinnabar mineral & Almaden (Ciudad Real/Castilla a la Mancha) & 8.365 & & \\
\hline Cinnabar mineral & Almaden (Ciudad Real/Castilla a la Mancha) & 7.51 & & \\
\hline Cinnabar mineral & Almaden S5 (Ciudad Real/Castilla a la Mancha) & 11.03 & & \\
\hline Cinnabar mineral & Almaden (Ciudad Real/Castilla a la Mancha) & 4.22 & & \\
\hline Cinnabar mineral & Almadén (Ciudad Real/Castilla a la Mancha) & 8.06 & & \\
\hline Cinnabar mineral & Las Cuevas mine (Ciudad Real/Castilla a la Mancha) & 18.3 & & \\
\hline Cinnabar mineral & El Entredicho mine (Almadenejos/Castilla a la Mancha) & 18.6 & & \\
\hline Cinnabar mineral & El Entredicho mine (Almadenejos/Castilla a la Mancha) & 15.3 & 16.7 & 1.71 \\
\hline Cinnabar mineral & El Entredicho mine (Almadenejos/Castilla a la Mancha) & 16.2 & & \\
\hline Cinnabar mineral & Puente Bachende Mine (Riaño/León) & 21.43 & & \\
\hline Cinnabar mineral & Puente Bachende Mine (Riaño/León) & 21.84 & & \\
\hline Cinnabar mineral & Puente Bachende Mine (Riaño/León) & 18.10 & 17.25 & 5.89 \\
\hline Cinnabar mineral & Pedrosa de rey mine (Boca de Huérfano/ León) & 17.6 & & \\
\hline Cinnabar mineral & Mina Escarlati (Puerto de las Señales, León)) & 7.29 & & \\
\hline Cinnabar mineral & Pola de Lena (Pola de Lena/Asturias) & 0.39 & & \\
\hline Cinnabar mineral & Eugenia mine (Pola Llena / Asturias) & 12.7 & 12.27 & 8.31 \\
\hline Cinnabar mineral & Maria de la Encarnación mine (Somiedo/Asturias) & 17.9 & & \\
\hline Cinnabar mineral & El Tarronal mine (La Peña/Asturias) & 18.1 & & \\
\hline Cinnabar mineral & Nieves mine (Torrelavega/Cantabria) & 5.88 & & \\
\hline Cinnabar mineral & Santa Cecilia mine (Arrive/Navarra) & 4.0 & & \\
\hline Cinnabar mineral & Arditurri (Ergoien/Gipuzkoa/P.Vasco) & -22.84 & -23.06 & 0.31 \\
\hline Cinnabar mineral & Arditurri (Ergoien/Gipuzkoa/P.Vasco) & -23.27 & & \\
\hline Cinnabar mineral & Xòvar (l'Alt Palància/Castelló) & -14.65 & & \\
\hline Cinnabar mineral & Betxi (Plana Baixa /Castelló) & -11.76 & -9.74 & 6.17 \\
\hline Cinnabar mineral & Assvela (L'Alt Palàcia/Castelló) & -2.81 & & \\
\hline Cinnabar mineral & Orihuela (Baix Segura/Alicante) & 7.27 & 7.27 & \\
\hline Cinnabar mineral & Castaras (l'Alpujarra/Granada) & -4.77 & -3.24 & 2.16 \\
\hline Cinnabar mineral & Baza (Baza/Granada) & -1.71 & & \\
\hline Cinnabar mineral & San Jose mine (Bayarque/Almeria) & 2.6 & & \\
\hline Cinnabar mineral & Mom CORDEROITA Mineral & -7.82 & & \\
\hline Pigments & BAR1a & 15.59 & & \\
\hline Pigments & BAR2a & 12.22 & & \\
\hline Pigments & BAR3a & 13.98 & & \\
\hline Pigments & BAR4a & 11.2 & & \\
\hline Pigments & BAR1d & 14.5 & & \\
\hline Pigments & BAR2d & 13.91 & 13.39 & 1.95 \\
\hline Pigments & BAR3d & 13.24 & & \\
\hline Pigments & BAR4d & 13.32 & & \\
\hline Pigments & BAR5d & 13.83 & & \\
\hline Pigments & BAR1e & 13.71 & & \\
\hline Pigments & BAR2e & 14.25 & & \\
\hline Pigments & BAR3e & 14.33 & & \\
\hline Pigments & BAR4e & 15.38 & & \\
\hline Pigments & BAR5e & 13.88 & & \\
\hline Pigments & BAR1M & 7.56 & & \\
\hline
\end{tabular}


Table 1. Cont.

\begin{tabular}{|c|c|c|c|c|}
\hline Type of Sample & Samples & S Isotopes & Mean Isotoìc Value & SD \\
\hline Pigments & PBAD13 & 14.7 & & \\
\hline Pigments & PBAD13 & 10.1 & & \\
\hline Pigments & PBAD13 & 11.4 & & \\
\hline Pigments & PBAD36 & 10.02 & 11.84 & 2.01 \\
\hline Pigments & PBAD36 & 11.6 & & \\
\hline Pigments & PBAD36 & 10.45 & & \\
\hline Pigments & PBAD46 & 14.6 & & \\
\hline Geological sample/cinnabar ore & Wanshan (Guizhou, China) & - & 22.58 & 3.62 \\
\hline Geological sample/cinnabar ore & Niu (Mie, Japan) & - & -7.26 & 1.85 \\
\hline Geological sample/cinnabar ore & Sui (Tokushima, Japan) & - & -2.38 & 1.44 \\
\hline Geological sample/cinnabar ore & Yamato (Nara, Japan) & - & -2.05 & 1.62 \\
\hline Geological sample/cinnabar ore & Monte Amiata (Siena, Italy) & - & -0.97 & 0.51 \\
\hline Geological sample/cinnabar ore & Erzberg (Eisenerz, Austria) & - & 0.65 & 3.47 \\
\hline Geological sample/cinnabar ore & Idria (Slovenia) & - & -1.33 & 0.5 \\
\hline Geological sample/cinnabar ore & Rudany (Slovakia) & - & -1.6 & 0.16 \\
\hline $\begin{array}{c}\text { Pigments } \\
\text { (Spangenberg et al., 2010) }\end{array}$ & Aventicum (Avenches, Vaud, Switzerland) & $10.9-8.7$ & 9.9 & 0.7 \\
\hline $\begin{array}{c}\text { Cinnabar mineral } \\
\text { (Spangenberg et al., 2010) }\end{array}$ & Almaden (Spain) & $8.9-(-0.5)$ & 4.3 & 3.5 \\
\hline $\begin{array}{c}\text { Cinnabar mineral } \\
\text { (Spangenberg et al., 2010) }\end{array}$ & Moschellandsberg (Germany) & $(-19.6)-(-15.6)$ & -17.6 & 2.5 \\
\hline $\begin{array}{c}\text { Cinnabar mineral } \\
\text { (Spangenberg et al., 2010) }\end{array}$ & Genepy (France) & $(-2.2)-3.5$ & -2.9 & 0.9 \\
\hline $\begin{array}{l}\text { Cinnabar mineral } \\
\text { (Higueras et al., 2000) }\end{array}$ & Almaden (Spain) & $9.00-(-1.6)$ & 5.3 & 7.4 \\
\hline $\begin{array}{c}\text { Cinnabar mineral } \\
\text { (Sauper and Arnold 1992) }\end{array}$ & Almaden (Spain) & $8.1-0.2$ & 4.15 & 6.1 \\
\hline $\begin{array}{l}\text { Cinnabar mineral } \\
\text { (García Gomez, et al., 2007) }\end{array}$ & Almaden (Spain) & 8 & 8 & 0 \\
\hline Cinnabar mineral & Abbadia San Salvatore (Italy) & $2-0.6$ & 1.3 & 2.6 \\
\hline Cinnabar mineral & Idria (Slovenia) & $3.2-1.5$ & 2.35 & 1.7 \\
\hline
\end{tabular}

\subsection{Analytical Routine and Measurements}

Sulfur is one of the main components of cinnabar (HgS). It occurs in four stable isotopes, i.e., ${ }^{32} \mathrm{~S},{ }^{33} \mathrm{~S},{ }^{34} \mathrm{~S}$, and ${ }^{36} \mathrm{~S}$, that can be found with the following proportions in nature, respectively: $95.02 \%, 0.75 \%, 4.21 \%$, and $0.02 \%$. The $\delta^{34} \mathrm{~S} \%$ value is the ratio of stable isotopes of sulfur $\left({ }^{34} \mathrm{~S}\right.$ and $\left.{ }^{32} \mathrm{~S}\right)$ in a sample against the equivalent ratio in a known reference standard:

$$
\delta^{34} \mathrm{~S}=\left(\left[\left({ }^{34} \mathrm{~S} /{ }^{32} \mathrm{~S}\right)_{\text {sample }} /\left({ }^{34} \mathrm{~S} /{ }^{32} \mathrm{~S}\right)_{\text {standard }}\right]-1\right) \times 1000
$$

The results are reported as variations from the standard ratio in parts per thousand per mill using the symbol: \%o. Presently, the most commonly used standard is Vienna-Canyon Diablo Troilite (VCDT). We measured only the two most abundant of those stable isotopes for reasons of accuracy and precision.

Archaeological paintings frequently contain gypsum $\left(\mathrm{CaSO}_{4} \cdot 2 \mathrm{H}_{2} \mathrm{O}\right)$, which may alter the $\mathrm{S}$ isotope values [36]. Therefore, we developed a new sampling method and improved the analytical infrastructure and methodology that have been used in previous studies [37,38]. Recently, Kazuya Takahashi and colleagues in the Astro-Glaciology Research Group developed a highly sensitive method for analyzing sulfur isotope ratios that only requires one microgram of cinnabar, which is about 500 micrograms less than what other methods need. This is important, because smaller samples necessitate less damage to artefacts [36].

Now, we use a new, ultrasensitive, ultratrace sulfur isotope analytical method that requires only a few milligrams of sample. Cinnabar is collected using a special $\mathrm{S}$ free tape from a very superficial external layer (only surface) of the paintings [16]. With this procedure, we reduce to almost zero the possibility of the alteration of the results due to $S$ 
that might come from the plaster and not the pigment. The samples are prepared in the following way: $4 \mathrm{~mL}$ of $0.1 \mathrm{M}$-EDTA- $4 \mathrm{Na} / 0.05 \mathrm{M}$-ammonium acetate solution (pH 4.0) is added to the cinnabar sample. It is mixed for $1 \mathrm{~h}$, and then the solution is dried and washed twice with $10 \mathrm{~mL}$ of ultrapure water. Next, the dried, precipitated samples are diluted in $4 \mathrm{~mL}$ of $0.1 \mathrm{M}$-EDTA-4Na/0.05 M-ammonium acetate ( $\mathrm{pH} 4.0$ ). After $1 \mathrm{~h}$ of mixing, it is dried up again and washed three times with $10 \mathrm{~mL}$ of ultrapure water. Then, the prepared sample is taken using a transparent $S$ free polyester adhesive tape $(2 \mathrm{~cm} \times 3 \mathrm{~cm})$, which is lightly pressed onto the prepared precipitate. The tape is folded in half, with the cinnabar sample facing inwards. Then, a $3 \mathrm{~mm} \times 3 \mathrm{~mm}$ piece of the folded tape is cut out and placed in an aluminum boat, which is introduced to the elemental analyzer: Vario ISOTOPE select, Elementar Analysensysteme $\mathrm{GmbH}$, a custom cryo-focusing device from Isoprime Trace gas, Elementar UK Ltd., Stockport, UK. Then it goes into the isotope ratio mass spectrometer: IsoPrime100, Elementar UK Ltd., Stockport, UK. In this system, $\mathrm{SO}_{2}$ gas is produced from the sample in the combustion tube of the elemental analyzer, which is followed by reduction. The $\mathrm{SO}_{2}$ is gathered by the cryo-focusing device, and then introduced to the mass spectrometer.

\section{Analytical Results and Discussion}

The analytical results are summarized in Table 1 (raw $\delta^{34} \mathrm{~S} \%$, the mean values and the standard deviations), which also includes some results from prior studies, such as results obtained for different Roman mural painting contexts in Baetulo (modern-day Badalona, $15 \mathrm{~km}$ NE of Barcelona) [8], and other values, available in the literature, for comparative purposes. We performed the comparison in two phases. First, we compared all the $\delta^{34} S \%$ ratios, both those obtained experimentally for mines and pigments and those that have been published, and we also added results from our previous works. Then, we compared the mean values of $S$ isotopes of pigments and mining areas, excluding those mines that are clearly not related to the origin.

Figure 3 is a boxplot of the $\delta^{34} \mathrm{~S} \%$ of all the sampled mines, of the Roman pigments from the domus Avinyó, and of the wall paintings from Badalona from our database [8]. It also includes values from the mines found in the existing literature and the pigments from Aventivum (Switzerland) [11]. The $\delta^{34} \mathrm{~S} \%$ oscillates between 7.56 and 15.59 in the pigments of the domus Avinyó (Table 1). Therefore, we can exclude as a possible source some of the Spanish or foreign mining areas due to their negative values (Figure 3). Those include all the sampled mercury mines from the Bask Country, Castelló, and Granada. The cinnabar of some of these mines, as indicated above, formed by the weathering of sulfides, thus inheriting their negative $\delta^{34} \mathrm{~S} \%$ values from the primitive sulfides ( $\mathrm{Hg}$-rich tetraedrite or sphalerite), which could be produced by bacteriogenic reduction.

Additionally, we can exclude as possible provenance areas Navarra, Cantabria, and the San José mine from Almería because of the lower values. Similar arguments can be used to exclude some Central Europe cinnabar mines based on the published data on them (Figure 3). Therefore, we can exclude Moschellandsberg (Germany), which presents highly negative values, Genepy (France), with values between -2.2 and 3, and Abbadia San Salvatore (Italy), which also exhibits relatively low values (between 0.6 and 2). For Idria (Slovenia), the literature provides values with high standard deviations (Table 1); the minimum values are around -1.33 , and the maximum values are around 8.8 . If we compare Idria with Almadén, no difference is observed regarding the absolute values, since Idria exhibits $S$ isotope values from -1.6 to 9.00. Nevertheless, Idria has already been excluded as a possible origin for cinnabar in Roman wall paintings with similar values [11]. As for the values that were detected in previous works for some Japanese mines, all are negative, so there is absolutely no match with our pigments; the same applies to the Chinese sulfur isotopes (Figure 3), for which the values of which are too high. That leaves us with a much shorter list of mines to consider as possible sources for our pigments. 


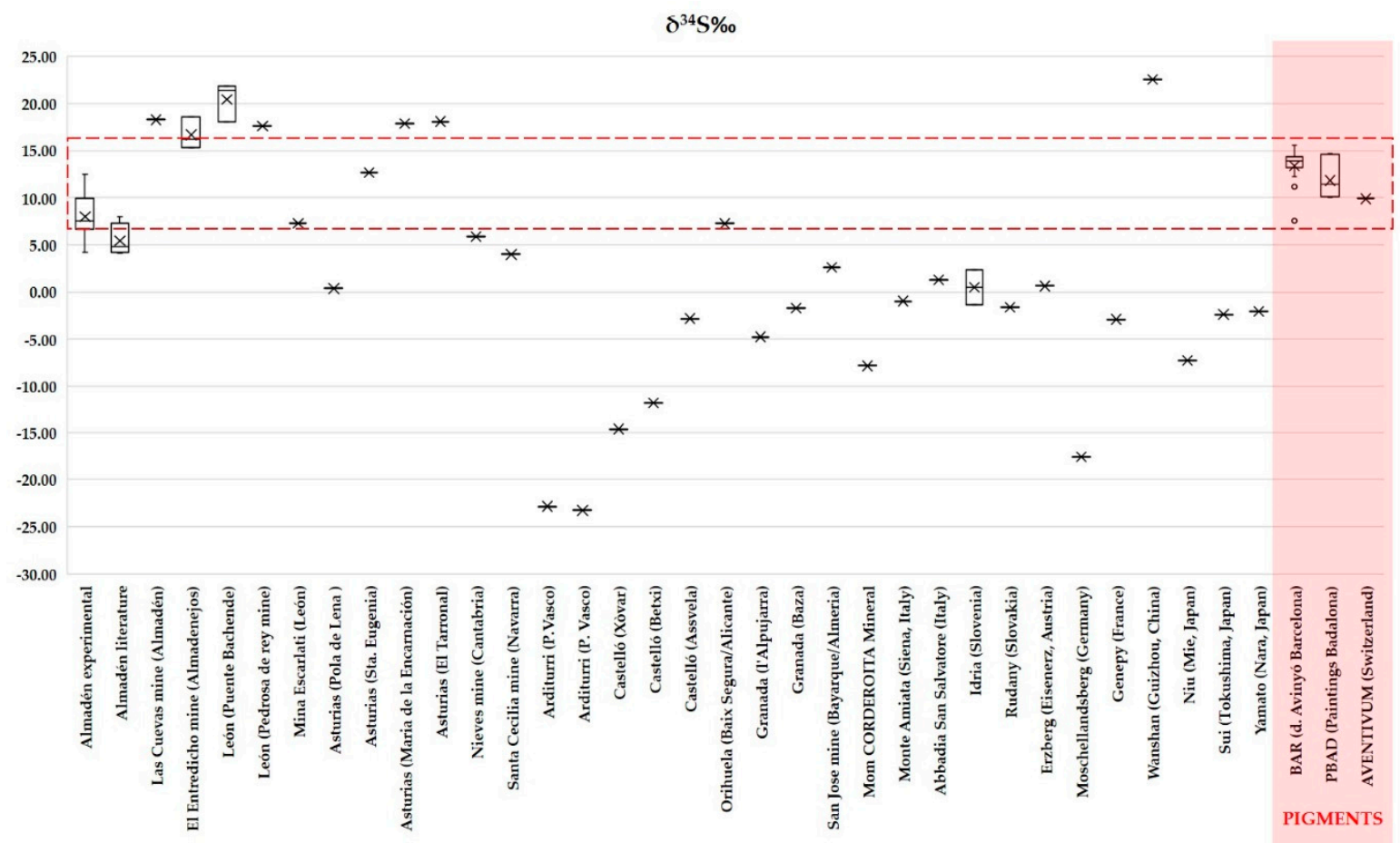

Figure 3. Boxplot of the $\mathrm{S}$ isotope values of all the sampled minerals and pigments, also including the values of previous works and those found in the literature.

At the same time, if we compare the values of the $\delta^{34} \mathrm{~S} \%$ of the domus Avinyó with those found in red pigments from Roman contexts in Badalona in our previous studies [8] (Table 1, Figure 3), they seem to have a plausibly common origin. Their values are also quite comparable to those that Spangenberg et al. [13] obtained for the pigments of Aventicum (Avenches, Vaud, Switzerland), for which the identified origin was Almadén (Table 1, Figure 3).

Now, departing from that reduced list of mines, we must consider three broad geological areas for possible provenance: Castilla a la Mancha (specifically the mining district of Almadén and Almadenejos), Asturias (besides Pola de Lena itself), and finally, León (all the mines in Riaño and Boca de Huérfano, but Escarlati the values of which are slightly smaller).

Almadén exhibits values that match with the lower isotopic values of the pigments, while the mines of Almadenejos (El Entredicho mine) and Asturias show values that are equivalent to their higher $\delta^{34} \mathrm{~S} \%$. Nevertheless, the El Entredicho mine (Almadenejos) is an open-pit mercury mine, the exploitation of which was carried out in the period 1978-1997. Even though the quality of the cinnabar crystals, associated either with mercury itself or to dolomite or quartz, is excellent, we can exclude this mine, since there is no information on its use in antiquity. Almadén, on the other hand, was identified as a possible origin for cinnabar in various studies of Roman mural paintings, as already mentioned. The high variability in cinnabar from Almadén (Table 1) is due to the fact that the deposits were formed by various geological processes (including hydrothermal alterations in volcanic rocks) or biogenic processes (involving the action of bacteria) in the district.

The variation of $\delta^{34} \mathrm{~S} \%$ in the Asturian mines is also considerable (Table 1). Pola de Lena itself barely shows 0.39 , while Sta. Eugenia, which is only a few kilometers from there, has isotopic values of 12.7; even higher are the values exhibited by Maria de la Encarnación in Somiedo and El Tarronal in La Peña (17.9-18.1). The mines located in western Asturias, as already stated, have been known and exploited since the Roman period (1st to 2nd centuries AD) [30]. Consequently, beside Pola de Lena itself and the Escarlati mine (because its value is slightly lower than the $\delta^{34} \mathrm{~S} \%$ ratios in the pigments), all 
the other mines (Sta. Eugenia, María de la Encarnación, and El Tarronal) must be seriously considered as possible sources of the studied cinnabar.

Finally, the $\delta^{34} \mathrm{~S} \%$ values for the mines sampled in León present low standard deviation (Table 1), though they are slightly higher than the isotopic values exhibited by the pigments (Figure 3). In Cantabria and León, there is also archaeological evidence of the exploitation of copper and cinnabar and mercury mines from prehistoric times, especially in the area of Riaño [33]. The Asunción mine, Pedrosa del Rey in León, was known to the Romans. They used this mine to obtain, among other metals, cinnabar and realgar. The mine was in continuous exploitation until the beginning of the 1970s. The mineral association includes crystallized cinnabar, fluorite, calcite, realgar, and stibnite as a replacement of black limestones. The Pedrosa de Rey mine (Boca de Huérfano / León) ensembles quite well with the results for the pigments and thus, according to the historical sources, cannot be excluded as a possible origin either.

Figure 4 presents a plot of the mean values and the mean and standard deviation or relative error of each of the mining areas and of all the pigments, excluding all the mines that cannot be considered as a possible source of the pigments. According to those values (Figure 4), we can exclude the mines of León, since the mean value was much higher than that of the pigments. That leaves us with only four equally valid possibilities: Alamadén (Ciudad Real) or the Asturian mines of Sta. Eugenia (Pola de Lena), María de la Encarnación (Somiedo), and El Tarronal (La Peña). The mean values of the Spanish Roman pigments, both from Barcino and Baetulo, were slightly higher than those of Aventicum, which better matched the mean values of Almadén (Figure 4), whereas our values seem to match better with the isotopic values of cinnabar sampled in the Asturian mines.

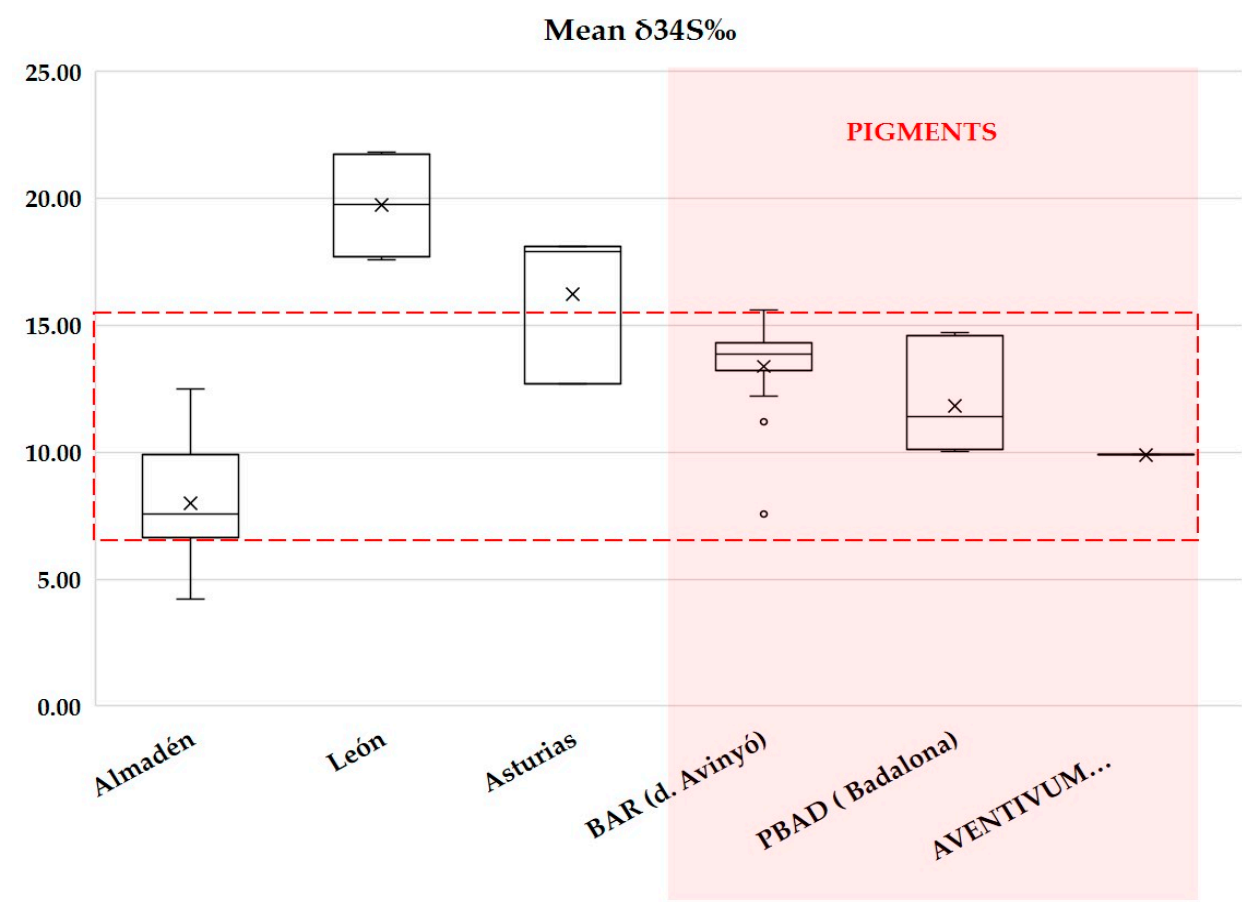

Figure 4. Mean and standard deviation between the minimum and maximum values for all the mining areas and the pigments.

\section{Conclusions and Further Considerations}

Cinnabar is the dominant red pigment in most prestigious Roman villas and public places with great social importance. The domus Avinyó is no exception; $80 \%$ of the red pigment in the important representation of the domus was identified as cinnabar. Cinnabar is the only red used in the wall paintings of the Triclinium and the Cubiculum. The scenes of 
Terpsichore and the muse and the imaginary architecture that surrounds it are all painted with cinnabar, which is already an important fact to consider regarding the social status of the villa. The only exceptions are the reds used in the auxiliary geometrical decorations, which are red ochre or hematite.

Our results indicate that the cinnabar used in the wall paintings of the domus Avinyó was not imported from outside the Iberian Peninsula. Moreover, based on our findings, some of the sampled Spanish mines can be clearly excluded as a possible source, such as those of the Bask Country, Castelló, Granada, Navarra, Cantabria, and San José mine in Almería. Based on the present results, Orihuela in Alicante, Pola de Lena itself (Asturias) and Escarlati (León) should be discarded. On the other hand, Almadenejos may be omitted for historical reasons. Finally, even though the values of the mines of León seem similar (Figure 5), the mean isotopic ratio of $S$ for that area is too high to consider it comparable to our painting samples, with the exception of Escarlati, the values of which were slightly lower than those of the pigments. This leaves us with two plausible mining areas that present similar sulfur isotopic values to those of the pigments: Castilla la Mancha and Asturias (Figure 5). These two mining areas are equally valid as possible areas of provenance according to both our results and historical information. Nevertheless, if we consider the mean isotopic ratios, the best match would be some of the Asturian mines: Sta. Eugenia in Pola de Lena, María de la Encarnación in Somiedo, and El Tarronal (Table 1). At the same time, there is no strong argument to exclude Almadén or Rot (another small mine in Almadén). Both of those mining areas were equally famous in ancient times for the extraordinary quality of their cinnabar. Almadén is known for both the vast extent and excellent quality of its cinnabar. The red coming from Sisinopo (Almadén) [2] was highly prized. Even though there is not as much historical information about the other mining areas as there is for Almadén, the fact is that we know the Asturian mines were used from the Megalithic/Early Bronze Age. The extent of the minerals in those mines is much less, though the quality is excellent. We also know that the Asturian cinnabar was highly prized in the Roman Empire as well [33].

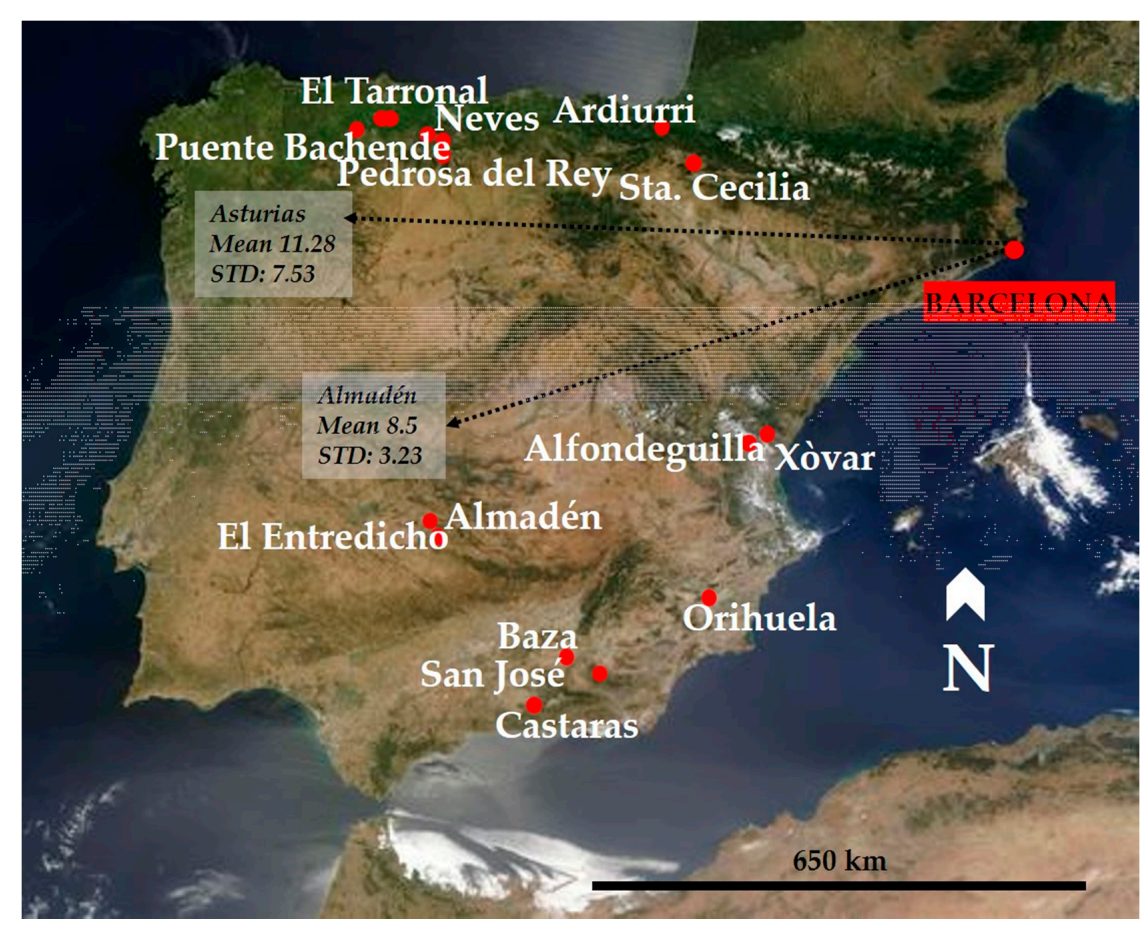

Figure 5. Indication of the possible provenance areas on the map with all the sampled mines.

Finally, even if the results prove that a single sulfur isotope analysis can be useful as a first assessment of the provenance of cinnabar, we need to extend the present analytical 
work to other isotopes, such as $\mathrm{Pb}$ and $\mathrm{Hg}$, to obtain more accurate results. Only then will we be able to glean more concrete information on the origin of the pigments due to the great intrasource variability of the sulfur isotopes as a result of the fact that their values are affected by the characteristics of chemical changes, certain biological phenomena, and physical phenomena that can vary extensively within the same ore deposit.

Lead is one of the few metal elements associated with cinnabar. Even if it is present as an impurity in the mercury minerals, it can be detected with much greater relative precision, and instead of one stable isotope (as is the case for sulfur), there are four stable isotopes of lead that can be measured with a high level of accuracy. There are already some results available for Roman wall paintings [23]. Lead isotopes are much more characteristic and stable across broader areas. Therefore, we have already started complementing these results with lead isotope analyses, and we expect to publish results soon.

Author Contributions: Conceptualization: E.T. and T.M.; Methodology: E.T., T.M. and K.T., Software: K.T., Validation: E.T., T.M. and M.Á.C.O.; Formal Analysis: T.M. and K.T.; Investigation: E.T. and T.M., Resources: E.T., T.M. and J.C.M.; Data Curation: K.T.; Writing-Original Draft Preparation: E.T., M.Á.C.O. and J.C.M.; Writing-Review \& Editing: E.T., M.Á.C.O. and J.C.M.; Visualization: E.T.; Supervision: E.T.; Project Administration: T.M.; Funding Acquisition: T.M. All authors have read and agreed to the published version of the manuscript.

Funding: This study is financially supported by Grants-in Aid for Scientific Research (A) (No. 26242016) and (C) (No. 18K01094) from the Japanese Society for the Promotion of Science.

Institutional Review Board Statement: Not applicable this study does not involve humans nor animals.

Informed Consent Statement: Not applicable this study does not involve humans nor animals.

Data Availability Statement: All data presented is original.

Acknowledgments: This work is also part of the activities of the Equip de Recerca Arqueològica i Arqueomètrica de la Universitat de Barcelona (ERAAUB), Consolidated Group (2017 SGR 1043), thanks to the support of the Comissionat per a Universitats i Recerca del DIUE de la Generalitat de Catalunya. Our deepest gratitude to the current staff to MUHBA, especially to Julia Beltrán, who helped us to obtain the analysed material and special thanks to the curator Lídia Fonts who helped us in the sampling of the pigments. A lot of reference samples were obtained from the reference collection of Mineralogy at the Departament de Mineralogia, Petrologia i Geologia Aplicada of the University of Barcelona, and from the Museu de Ciències Naturals de Barcelona (Marc Campeny). We also thank other mineralogists, especially Bálint Péterdi, of the Geological and Geophysical Institute of Hungary, and Marco Lezzerini, of the University of Pisa, for their help in the collection of other European cinnabar samples.

Conflicts of Interest: The authors declare no conflict of interest.

\section{References}

1. Isidoro de Sevilla, I. Etimologías II, 2nd ed.; Reta, J.O., Marcos Casquero, M.A., Católica, S.A., Eds.; Biblioteca de Autores Cristianos, 434; Madrid Publicación Católica: Madrid, Spain, 1983.

2. Vitruvio Polion, M. Los Diez Libros de Arquitectura, 2nd ed.; Ortiz, J., Rodríguez Ruíz, S.D., Eds.; Ediciones AKAL: Madrid, Spain, 1992.

3. Abad-Casal, L. La pintura Romana en España. In $1^{R}$ coloquio de Pintura Mural Romana en España: Actas del Coloquio Organizado por la Asociación de Pintura Mural Romana en Hispania; Jiménez Salvador, J.L., Ed.; Ministerio de Cultura, Generalitat Valenciana; Departament de Prehistòria i Arqueologia de la Universitat de València: València, Spain, 1992; pp. 13-24.

4. $\quad$ Augusti, S. I Colouri Pompeiani, 2nd ed.; De Luca Editore: Roma, Italy, 1967.

5. Barbet, A.; Delmare, F.; Monier, F.; Vindry, G.; Wallet, M. Les peintures romaines de Lero au Musée de la Mer: Dans l'Ill Sainte-Marguerite (Iles de Lérins). Revue du Louvre Études 1999, 3, 37-46.

6. Colombo, L. I Colouri Degli Antichi; Nardini Editor: Fiesole, Italy, 1995.

7. Secundi, P. Naturalis Historia, 2nd ed.; Russos, T., Levidakis, A., Eds.; АГРА: Athens, Greece, 1998.

8. Tsantini, E.; Takeshi, M.; Takahashi., K.; Cau, M.A. Analysis of sulphur isotopes to identify the origin of cinnabar in the Roman wall paintings from Badalona (Spain). J. Arch. Sci. Rep. 2018, 18, 300-307. [CrossRef]

9. Martín-Gil, F.J.; Delibes-de-Castro, G.; Zapatero-Magdaleno, P.; Sarabia-errero, F.J. The first known use of vermillion. Experientia 1995, 51, 759-761. [CrossRef] [PubMed] 
10. Mazzocchin, G.A.; Agnoli, F.; Mazzocchin, S.; Colpo, I. Analysis of pigments from Roman wall paintings found in Vicenza. Talanta 2003, 61, 565-572. [CrossRef]

11. Spangenberg, J.E.; Lavric1y, J.V.; Meisser, N.; Serneels, V. Sulfur isotope analysis of cinnabar from Roman wall paintings by elemental analysis/isotope ratio mass spectrometry-Tracking the origin of archaeological red pigments and their authenticity. Rapid Commun. Mass Spectrom. 2010, 24, 2812-2816. [CrossRef] [PubMed]

12. Elert, K.; Cardell, C. Weathering behavior of cinnabar-based tempera paints upon natural and accelerated aging. Spectrochim. Acta Part A Mol. Biomol. Spectrosc. 2019, 216, 236-248. [CrossRef]

13. Schmitt, A.K.; Martin, D.; Erkan, A.; Erdal, Ş.; Lovera, O.M. Identifying the Volcanic Eruption Depicted in a Neolithic Painting at Çatalhöyük, Central Anatolia, Turkey. PLoS ONE 2014, 9, e0084711. [CrossRef]

14. Huarto-Pérez, V. Informe sobre las Excavaciones en la Pijotilla (Badajoz). Extremad. Arqueol. 1988, 1, 35-54.

15. Pavón-Soldevila, I.; Rodríguez-Díaz, A.; Enríque-Navascués, J.J.; Duque-Espino, D.M. La investigación en Extremadura prehistórica los últimos 25 años. Norba. Rev. Hist. 2009, 22, 31-55.

16. Saupé, F. Geology of the Almadén Mercury Deposits, Province of Ciudad Real, Spain. Econ. Geol. 1990, 85, 482-510. [CrossRef]

17. Saupé, F.; Arnold, M. Sulphur isotope geochemistry of the ores and country rocks at Almadén mercury deposits, Ciudad Real, Spain. Geochim. Cosmochim. Acta 1992, 56, 3765-3780. [CrossRef]

18. Calderón, S. Los Minerales de España; Tomo, I., Ed.; Imorenta de Eduardo Arias: Madrid, Spain, 1910.

19. Jébrak, M.; Higueras, P.; Marcooux, É.; Lorenzos, S. Geology and geochemistry of high-grade, volcanic rock-hosted, mercury mineralization in the Nuevo Entredicho deposit, Almadén district, Spain. Miner. Depos. 2002, 37, 421-432. [CrossRef]

20. Hunt-Ortiz, M.A. Prehistoric Mining and Metallurgy in South West of the Iberian Peninsula; BAR International Series 1188; Arqueopress: Oxfrod, UK, 2003.

21. Hernández, A.; Jébrak, M.; Higueras, P.; Oyarzun, R.; Morata, D.; Munhá, J. The Almadén mercury mining district, Spain. Miner. Depos. 1999, 34, 539-548. [CrossRef]

22. García-Gómez, M.; Caballero-Klink, D.J.; Boffetta, P.; Español, S.; Sällsten, G.; Gómez-Quintana, J. Exposure to mercury in the mine of Almadén. Occup. Environ. Med. 2007, 64, 389-395. [CrossRef] [PubMed]

23. IGME. Mapa Metalogénico de la Provincia de Badajoz; Escala 1:200.000; Instituto Geológico y Minero de España y Dirección General de Ordenación Industrial, Energía y Minas: Junta de Extremadura, Spain, 2006.

24. Higueras, P.L.; Munhá, J.; Oyarzun, R.; Tassinari, G.I.; Ruiz, R. First lead isotopic data for cinnabar in the Almadén district (Spain): Implications for the genesis of the mercury deposits. Geogazeta 2005, 37, 67-70. [CrossRef]

25. Higueras, P.L.; Oyarzun, R.; Munha, J.; Morata, D. The Almaden Mercury Metallogenic Cluster (Ciudad Real, Spain): Alkaline Magmatism Leading to Mineralization Processes at an Intraplate Tectonic Setting. Rev. Soc. Geológica España 2000, 13, 105-119.

26. Hall, C.M.; Higueras, P.L.; Kesler, S.E.; Lunar, R.; Dong, H.; Halliday, A.N. Dating of alteration episodes related to mercury mineralization in the Almadén district, Spain. Earth Planet. Sci. Lett. 1997, 148, 287-298. [CrossRef]

27. Calvo, F.A.; Guilemany, J.M.; Gómez Salazar, J.M. Estudios Sobre la Estructura y Consideraciones sobre la Génesis de las Menas de Mercurio: VI Yacimiento de Usagre (Badajoz). Rev. Real Acad. Cienc. Exactas Físicas Nat. 1985, 78, $267-284$.

28. Ortega Girones, E.; Hernández Sobrino, A. The mercury deposits of the Almadén syncline, Spain. Chron. Rech. Min. 1992, $506,3-24$.

29. Rodríguez-Terente, L.M.; Luque-Cabal, C.; Gutiérrez-Clavero, M. Los registros mineros para sustancias metálicas en Asturias. Trab. Geol. Univ. Oviedo 2006, 26, 19-55.

30. Barbanson, L.; Saulas, D.; Touray, J.C. Les blendes mercurifères de la región de Cabezón de la Sal (Santander, España). Bull. Miner. 1985, 108, 483-486. [CrossRef]

31. Loredo, J.; Luque, C.; García-Iglesias, J. Conditions of formation of mercury deposits from the Cantabrian Zone Spain. Bull. Minéral. 1988, 111, 393-400. [CrossRef]

32. Luque, C.; Garcia, J.; García, P. Características Geoquimicas de los Cinabrios de la Cordillera Cantábrica (NW de España): Utilidad en prospección. Trab. Geol. Univ. Oviedo 1989, 18, 1-11.

33. Neira-Campos, A.; Alonso-Herrero, E.; Matías-Rodríguez, R.; Fuertes-Prieto, N.; Pérez-Ortíz, L.; San Román-Fernándes, F. La más antigua minería metálica en tierras de León. In El hallazgo leonés de Valdevimbre y los depósitos del Bronce Final Atlántico en la Península Ibérica; Junta de Castilla y León, Consejería de Cultura y Turismo, Diputación de León, Instituo Leonés de Cultura: León, Spain, 2007; pp. 220-223.

34. Tritlla, J.; Cardellach, E. BaHg deposits in the Espadán ranges (Iberian Chain, Eastern Spain): An example of Cretaceous fluid circulation and Alpine overprinting. J. Geochem. Explor. 2003, 78-79, 579-584. [CrossRef]

35. MUHBA. El domus Avinyó; Barcelona Inspira, Ajuntament de Barcelona: Barcelona, Spain, 2015.

36. Minami, T.; Hatanaka, K.; Motizuki, Y.; Nakai, Y.; Takahashi, K. A method of collecting trace amounts of vermilion from artifacts for source estimation by sulfur isotope $\left(\delta^{34} \mathrm{~S}\right)$ analysis: Use of sulfur-free adhesive tape to minimize damage to the artifact body during sampling. J. Arch. Sci. Rep. 2018, 28, 102027. [CrossRef]

37. Kawano, M.; Tokuda, M.; Imazu, S.; Minami, T. Determination of original mine of vermilion collected from ancient burial mounds in Japan using an improved sulphur isotope analytical method for small amounts of vermilion. J. Appl. Laser Sect. 2014, 1, 37-40.

38. Minami, T.; Imai, A.; Bunno, M.; Kawakami, K.; Imazu, S. Using sulfur isotopes to determine the sources of vermilion in ancient burial mounds in Japan. Geoarchaeology 2005, 20, 79-84. [CrossRef] 